\title{
A QUALITATIVE RESEARCH ON SELECTED PERFORMANCE INDICATORS FOR INVESTMENT DECISION PROCESS: A FRAMEWORK FOR FINTECH STARTUPS IN TURKEY
}

\author{
DOI: 10.17261/Pressacademia.2020.1190 \\ JBEF- V.9-ISS.1-2020(3)-p.28-41
}

Sema Nur Altug Fayda1, Abdulkadir Sencan², Ozgur Aksoy ${ }^{3}$, Selim Yazici ${ }^{4}$

${ }^{1}$ Istanbul University, Department of Business Administration, Management and Strategy PhD. Candidate, Istanbul, Turkey. sfayda@yahoo.com , ORCID: 0000-0003-2985-9866

${ }^{2}$ Istanbul University, Department of Business Administration, Management and Strategy PhD. Candidate, Istanbul, Turkey. abdulkadirsencan@gmail.com , ORCID: 0000-0001-7337-6218

${ }^{3}$ Istanbul University, Department of Business Administration, Management and Strategy PhD. Candidate, Istanbul, Turkey. aksoyozgur@gmail.com, ORCID: 0000-0003-3217-6417

${ }^{4}$ Istanbul University, Faculty of Political Sciences, Department of Business Administration, Istanbul, Turkey. selim@istanbul.edu.tr, ORCID: 0000-0001-7953-2496

Date Received: January 15, 2020

Date Accepted: March 24, 2020

To cite this document

Fayda, S.N.A., Sencan, A., Aksoy, O., Yazici, S. (2020). A qualitative research on selected performance indicators for investment decision process: a framework for fintech startups in Turkey. Journal of Business, Economics and Finance (JBEF), V.9(1), p.28-41.

Permemant link to this document: http://doi.org/10.17261/Pressacademia.2020.1190

Copyright: Published by PressAcademia and limited licenced re-use rights only.

\begin{abstract}
Purpose- The purpose of this study is to help investors in their decision-making process in funding Financial Technology (FinTech) Startups by developing a framework of key performance indicators for effective financial resource allocation. A better understanding of investors' point of view for FinTech Startups is also targeted.

Methodology- The study is conducted as structured face-to-face interviews with a sample of four angel investors and four venture capitals. In the interviews, selected indicators from the literature and finance industry experts' declarations were presented in four groups: Firm, Owner/Founder, Financial or Marketing/Procurement Characteristics. It was asked whether these indicators were used in the decisionmaking process or were there extra indicators not listed here.

Findings- The widely accepted indicators were found shareholder structure, experience of major decision makers, increase in net sales, existence and amount of VC or other funding, number of clients, serving to consumers or businesses and expected developments in the startup's sector.

Conclusion- Results of this study may help investors in their decision-making process in funding FinTech Startups FinTech startups are also targeted to have a better understanding of investors' point of view. This study contributes to the common understanding on investment dynamics in Turkish FinTech ecosystem, which is expected to have a major role in FinTech industry.
\end{abstract}

Keywords: Financial technology, venture capital, angel investor, investment decision, performance indicators JEL Codes: G11, G24, M13

\section{INTRODUCTION}

FinTech can be defined as "a dynamic segment at the intersection of the financial services and technology sectors' or 'a revolution in the financial services industry, bringing innovation to the products and services currently provided by the traditional financial services industry", or "simply the technology innovations supporting financial services companies and their customers" (Sironi 2016; Arner et al., 2015).

The real rise of FinTech in the world was after 2005, with the acceleration of digitalization and globalization. During this FinTech 1.0 period, there were attempts to improve banks' existing services, as well as attempts to replace banks. After 2010, FinTech 2.0 period came as a collaboration-based era, in which a great deal of visibility was captured at the FinTech. Many banks began to invest in FinTech companies with the funds they organised or created funds to invest as soon as they realised that the dynamic FinTech companies could help themselves. In the FinTech 3.0 period the world has recently realised that financial sector would further improve the diversity and quality of their services by integrating new technologies and solutions such as cloud, artificial intelligence and API into their systems (Canko, 2017). 
Global FinTech investment in 2015 grew by $75 \%$, from $\$ 9.6$ billion to $\$ 22.3$ billion with an average annual growth pace of $\% 27$, according to 2016 Accenture analysis on CB Insight data(2016). Since 2010, more than $\$ 50$ billion has been invested in FinTech companies (approximately 2500); $\$ 5.3$ billion being in the first quarter of 2016 with a continuous increase in deal sizes despite the signs of the FinTech industry's tendency to a new level of maturity with some regions cooling-off.

According to the Price Waterhouse Coopers (PwC) 2016 Global FinTech Report: Blurred lines: How FinTech is shaping Financial Services; it is estimated that the global cumulative FinTech investment may exceed $\$ 150$ billion within the next 3-5 years, and the main trends in FinTech industry lies in cybersecurity, self-directed services, enhancing customer experience and refined data analytics depending on Financial Services segment. Based on PwC Global FinTech Survey with 544 respondents across 46 countries, consumer banking (80\%), fund transfer and payments $(60 \%)$, investment and wealth management (38\%) and SME Banking (35\%) sectors are expected to be affected by FinTech dramatically in the following 5 years. $75 \%$ of the respondents think increased focus on the customer as the most important impact, 83\% accepting the risk of losing part of their businesses to FinTech companies, 20\% claiming there is a risk that FinTechs dispossess more than $20 \%$ of Financial Services business by 2020 (PwC Global FinTech Survey, 2016).

Haddad and Hornuf (2016) investigated the economic and technological determinants inducing entrepreneurs to establish FinTech ventures, and found that when the latest technology is readily available, capital markets are well-developed, where people have more mobile phone subscriptions and which have available labor force, meaning higher availability to enjoy more FinTech startup formations.

Confirming Haddad and Hornuf's investigation, we can speak of four core attributes for a FinTech Ecosystem (E\&Y Independent Report, 2016):

- Talent (Technical, financial services and entrepreneurial talent ability),

- Capital (Sufficiency for startup and scale-up financing),

- Policy (Issues related with regulations, tax and sector growth of government policy),

- Demand (Demand of end-users like financial institutions, consumers and corporates).

The purpose of this study is to help investors in their decision-making process in funding FinTech Startups in Turkey and to develop a framework for effective allocation of financial resources by using selected performance indicators. In addition, it is thought that FinTech startups' benefiting from the knowledge of the preferred indicators would assist the development of Turkey resident FinTechs' core attributes such as talent pool, capital structure, corporate governance and demand expansion.

\section{LITERATURE REVIEW}

\subsection{FinTech Ecosystem in Turkey}

As of December 2016, there were around 140 FinTech startups in Turkey, operating in 27 different verticals. These include payment systems, personal finance, digital banking, off-line banking, schemes, and money transferring. Some others develop mobile applications and alternative distribution channels solutions (Capital, 2017a). Growth potential for FinTechs in Turkey mainly lies in InsurTech, blockchain technology, contactless payments, loT and API banking (Yazici, 2017).

Turkey is expected to have a major role in FinTech industry with the help of strengthening foreign banking investments, banking industry's crisis management experience, and high credit/debit card penetration factors (Capital, 2017a). The transaction value in Turkish FinTech ecosystem has become $\$ 14.7$ billion and it is expected to reach \$28.4 billion by 2021 (Statista Capital, 2017b).

ING International survey (2015) states that Turkey has the highest shares of mobile banking users among internet users. Registered customers' total number (with at least one log-in to their account) was 27 million as of September 2016, and 61\% of total customers (17 million) used mobile banking services in period of July-September 2016 (BAT, 2016).

Turkey has high percentages of young population, which is keen on internet and mobile use. The readiness of the young (aged 15 to 34) population in Turkey for using financial services (especially mobile payments) is a revealed fact by MasterCard in 2016. Due to the young, diversified, technology-literate and educated manpower including returner worker and students from the US and Europe, Turkey has a good capability in supplying the expanding demand for online ecosystems, new business models and digital media (Belli, 2016).

With its flourishing economy, suitable climate for investment, high-quality resources, infrastructure for business and its strategic location between Asia, Middle East and the Europe, Turkey has the potential to become a regional Information and Communications Technology (ICT) hub (Belli, 2016). In the Turkish National Technology Foresight Program, Vision 2023, the Government has an objective for increasing the sector spending for ICT to 8\% of Gross Domestic Product (GDP) (E\&Y 2013). FinTech companies may receive grants from the Turkish Government and various public organizations for their R\&D projects 
(Capital, 2017a). Turkish government also supports collaboration with universities to establish science, technology and business integration via the Centers and Technoparks (i.e. BIST FinTech Technopark, Özyeğin University Istanbul Risk Management Lab). The Istanbul Financial Center Initiative (IFC-I) has been launched by the Turkish Government in 2009, aiming to make Istanbul a global financial center. Turkey is planning to make all transactions with payment systems to become the first country without cash in the world by 2023 . However, the state of infrastructures, unbanked population size and the cash usage habits remain as the main pitfalls to become a cashless society (Belli, 2016).

The startup hub of Turkey, Istanbul, is a popular area for Turkish FinTech startups with the advantages of having a young and talented design and development force, having lower labor costs, strength in e-commerce, being closer to the financial center, and its flourishing brand value. Besides the advantages of being in Istanbul, there exist also disadvantages: Not only Turkish FinTech startups, but also Turkish startup ecosystem experience some challenges such as lack of marketing, brand culture and institutional investors. Many entrepreneurs are afraid of failure in Turkey. Main challenges for the sector are existing business standards, regulations, customer relations management, and edifying customers about innovative technologies, which are contributing to business processes (Belli, 2016).

\subsection{Turkish Banking Industry's Interest for FinTechs}

Thanks to Turkey's transformation into a digital hotspot over the years, the Turkish banking sector has been very innovative, providing latest technology products to customers, such as applications for payment and banking in mobile platform (pymnts.com, 2013 as quoted in Belli, 2016; Drucker, 2013). Banks in Turkey are successful in using new technologies for customer acquisition and engagement or in accepting and using innovative technologies for the first time (i.e. digital wallets, talking ATMs, biometric ATMs, digital banking services and mobile applications, and their apps on multiple platforms, wearable technologies, contactless cards) (Belli, 2016). The Turkish banking sector is a kind of an innovation cluster where one entity's innovation leads others' adoption and moving it forwards. This creates a speedy cycle of innovation within the industry (Ensor, 2012). Sector mainly prefers developing technologies in-house, but major banks in Turkey rethink co-working with the experts in sub-areas with disruptive, agile and innovative FinTech startups for being more competitive and innovative. Some Turkish banks support FinTech firms via FinTech hackathons or strategic alliances. (Belli, 2016).

To be successful in adopting new technologies, the high population and the population's readiness for internet and mobile usage are big advantages for the Turkish banking sector. On the contrary, the high percentage of unbanked and the underbanked population arise as a challenge. Therefore, there is an effort from banks to reach this unbanked population by innovative banking technologies (Belli, 2016).

Regulations for FinTech looks like a bold development area in Turkey. Negotiations to simplify regulations for new technologies' implementation go on between the Turkish banking sector and the regulatory authorities (Belli, 2016). The regulation change that made licensing from Banking Regulation and Supervision Agency (BRSA) compulsory is expected to lower FinTech companies' speed in entering the industry because of the new investment and time requirements it brought. However, this can also catalyze the collaboration between banks and FinTech startups (Capital, 2017a).

\subsection{FinTech Companies}

For many years, financial technologies served only to back and middle offices, because front offices have been thought as labor-intensive and relationship-based (Boteler, 2014). However, this is not the case nowadays as they cover all. Customer segments have expanded by including small and medium enterprises (SMEs), big companies, advisors, asset managers, and hedge funds (Belli, 2016).

Organizations in global financial services sector can utilize Financial Technologies in mobile and retail banking, transactions and payments, crowd funding, digital wallets, PR practices, digital and alternative currencies, commodities markets, peer-topeer (P2P) lending, risk and compliance, customer onboarding, foreign exchange (FXT) and trading, privacy and security, risk management, more efficient financial advisory services and insurance. Banks in Turkey demand wallet, beacon and ATM projects as well as mobile banking solutions from FinTech companies (NDRC, 2014).

FinTech companies serve four main customer groups (NDRC, 2014):

- The first group consists of the large and long-established financial services institutions with complex value chains and long sales cycles, which can be identified under business-to-business (B2B) segment.

- The second group contains financial organizations' customers, asset managers, brokers, advisors, corporates and Small and Medium Enterprises (SME) that are also mapped under B2B segment.

- The third group includes alternative seeking small businesses for banking and capital sources, under business-toconsumer (B2C) segment.

- The last group includes best-dealer consumers preferring online banking, and is also identified under B2C segment. 
In today's digital economy FinTech startups play a major role in financial technology sector. Many countries try to create environments where they can attract and capture startups from all around the world. Creating a 'FinTech friendly business climate' where startups can flourish easily, countries can also attract investments and create knowledge transfer. Countries like UK, Singapore, USA, Germany, Hong Kong, India, and UAE are amongst the best countries, which can encourage global engagement, and knowledge sharing, as well as building bridges between entrepreneurs and investors. They also invest heavily to become a FinTech Hub by introducing new regulations as well as funding mechanisms.

\subsection{Funding of FinTech Startups}

FinTechs may obtain funds from various resources, such as venture capital firms, angel investors, government banks and other corporations.

Venture Capital companies are institutions providing funds to the early stage, emerging firms that exhibit growth potential. Venture Capital companies can be organised in the following ways, the limited partnership being the most common form (Rozen, 2015):

- Publicly traded,

- Large bank or corporation's captive subsidiary,

- Small business investor,

- $\quad$ Private limited partnership (Barry 1994 from Rozen, 2015).

Angel Investors are mostly informal, unstructured risk capital providers into new ventures. They exhibit some kind of entrepreneurial-oriented behavior and do not count return on investment as the only factor behind their investment decisions (Karabayır et al., 2012).

Banks and technology firms organise acceleration and incubation programs, which have positive effects on the growth of sector. FinTech specific venture capital companies, acceleration and incubation programs are also widening worldwide, as well as 'sandbox' environments facilitating international testing capability for FinTech products (Yazici, 2017). According to the PwC DeNovo platform companies, FinTech startups have raised $\$ 12.2$ billion in 2015 in the world, reaching more than two-folds of 2014 number, $\$ 5.6$ billion (PwC, 2016). Funds for FinTechs mostly come from non-bank sources in the global environment. Although banks are willing to cooperate with FinTechs via alternative ways like hackathons, partnerships or incubation centers, they represent only $4 \%$ of total FinTech investments in the world (Cengiz, 2017). In Turkey, VCs and Angels invested nearly $\$ 42$ million in FinTech startups in the last 5 years, half of it being in 2016. FinTech growth potential is expected to be $10 \%$ and $15 \%$, in the world and in Turkey respectively (Capital, 2017b). Top ten FinTech Accelerators worldwide are Dassault Systems, 500 Startups, Anthemis Group, Axel Springer Plug and Play Accelerator, Barclays Accelerator, Citi Ventures, FinTech Innovation Lab, Founder Institute, Fusion, Launchub (360Leaders, 2016; letstalkpayments, 2016). Some of the institutional FinTech investors in Turkey are Revo Capital, 212, Earlybird, MV Holding, Endeavor Catalyst, Speedlnvest, 500 Startups, Nexus Ventures Pahicle Invest, Esor Investments, Mastercard PTS, Primary Door, Smryna Capital, Ribbit Capital, IFC, Beenos, and Mediterra Capital Partners.

\subsection{Selected Performance Indicators for Funding: A Literature Review}

To gain an insight about the performance indicators emphasized by the investors in evaluating startups, preferably FinTech or related, a short review of literature has been conducted:

MacMillan et al. (1986) tried to determine the criteria they use for the decision to fund a venture based upon interviews with more than a hundred venture capitalists. Åstebro and Bernhardt (2003) were in search for a connection between the bank credits and new small businesses' survival. They used small business survival versus measures for (1) if the firm had bank and/or other loans at time of startup; (2) proxies for human capital; and (3) descriptives for industry and company, using a probit survival model. In the study of Cassar (2004), capital structure determinants and business startups' financing types have been investigated. They used four interrelated capital structure and financing indicators to investigate characteristics for financing of startups empirically: leverage (short and long-term), financing (outside and bank).

Baum and Silverman (2004) investigated VCs' decisions to finance biotechnology startups with the effects of startups' intellectual, human capital and alliance aspects on future startup performance. They questioned VCs by comparing the same characteristics to find out whether they are picking winners or building them. Davila and Foster (2005) investigated a relation between startup performance and management account systems adoption in early stage startup companies in their 2005 study, which is examined for this study by means of the measures of startup performance. Ensley et al. (2006) compared the top management teams of new ventures by means of vertical and shared leadership with respect to their relative influence on the performance of startups. This study is also in our interest by means of performance measures for startups. Csaszar et al. (2006) proposed a decision aid for venture capitalists to improve their decision-making processes, complementing 
strategic criteria with cognitive ones. Eckhardt et al. (2006) studied selection criteria of VC's from founders' perspective and selection criteria of startups from financiers' perspective and their findings support that the founders' selection of ventures as external finance source is arising from their perceptions of competition in the market and growth of the employment and market. However, funding decisions of financiers are based on verifiable and objective indicators of venture development, like the sales level and the completion of organizing and marketing activities. Parker (2009) explained the determinants of entrepreneurship in his insightful book 'The Economics of Entrepreneurship'. Nofsinger and Wang (2011) examined entrepreneurial firms in 27 countries to find out the markers of the first-stage startup financing by using logit regression mainly on Global Entrepreneurship Monitor (GEM) data. They investigated the responses of informal and institutional investors to three kind of indicators: type of the product (existing vs. new), production technology (existing vs. new), and the entrepreneur's experience. Miloud et al. (2012) tried to explain new venture valuation process of a venture capitalist by important firm performance factors identified in the strategy theories in an integrated theoretical framework using Thomson Financial Securities data. Groenewegen and Langen (2012) studied the factors that are most important for the success of a startup with a radical innovation in the first three years. Chang (2013) compared the selection of portfolio companies between accelerators and venture capitalists. Nanda and Rhodes-Kropf (2013) used multivariate analysis to find out if there existed any systematic difference in the forms of VC-funded startups. Using Dow Jones Venture Source, they studied the venture capital funded firms at the early stage between 1985 and 2004 by means of financial and innovation outcomes. Cusumano (2013) tried to help potential investors and nascent entrepreneurs in evaluating startup ventures more systematically with a short checklist of key items based on his experience and a list published in The Business of Software in 2004. Cassar (2014) studied the industry and startup experience influence on the forecast performance of the entrepreneur using the Kauffman Firm Survey and found that industry experience leads to more accurate and less biased entrepreneur expectations, which provide more benefit in high-technology industries. An et al. (2015) used full model regression on Angellist (one of the largest global equity-based crowdfunding investment platform) data. This study investigates the relationship between the amount of funds and the underlying characteristics of early stage startups, the past investors' type, and influence of investors in the context of equity-based crowdfunding. Marion (2016) gave information about a 2015 analysis published by the venture capital firm First Round Capital on venture capital investment success. Wimmer (2016) proposed to use the iterative business model concept to understand the path from the starting point into new ventures. The study investigated how entrepreneurs in the digital space transform vague opportunities. Staniewski (2016) investigated the association between success and selected predictors of organization and found that entrepreneurs having experience in management, with an entrepreneur in his family, his employees or he himself having unique knowledge, express higher mean scores in the general indicators of entrepreneurial success (annual turnover, survival, competitiveness, profitability, future opportunities for business development, liquidity and innovativeness). Nuscheler (2016) aims to solve existing unclearness on signals to attract venture capitalists and proposes a round-specific model, also accounting for moderating effects from repeat investors by using logit model on Crunchbase data. Falik et al. (2016) investigated the impact of startup experience on entrepreneurs' trade-offs between criteria related to resources or to the conditions of the deal.

This focused review was performed to scan the literature about FinTech investment criteria in order to end up with a questionnaire that can be presented to investors and startups. Final aim of this study is to figure out the relationship between investors investment decision and the evaluation process.

\section{DATA AND METHODOLOGY}

\subsection{Determination of Performance Indicators}

To determine the performance indicators that can be used in an evaluation process, a literature review has been conducted. According to FinTech 100 report, more than half of the top 50 FinTech 'unicorns' were born after 2010 (FinTech 100 report by KPMG and H2 Ventures, 2016). Therefore, a time frame between January 2010 to December 2016 was chosen for literature review and EBSCO Host Business Source Complete Database was scanned for the key search words listed below (for all fields, results in parenthesis):

a) 'FinTech Assessment Criteria' (5),

b) 'FinTech Evaluation Criteria' (10),

c) 'FinTech Success Factors' (32),

d) 'FinTech Performance Indicators' (22),

e) 'FinTech Scorecard' (0),

f) 'FinTech investment' (8),

g) 'Startup Assessment Criteria' (0),

h) 'Startup Evaluation Criteria' (0),

i) 'Startup Success Factors' (0),

j) 'Startup Performance Indicators' (0), 
k) 'Startup Scorecard' (4),

l) 'Startup investment' (0).

50 out of 72 solutions (9 repeated) were irrelevant or couldn't have reached in full text by the researchers, so remaining 22 (a) has taken into consideration. $g, h, i, j, I$ searches also brought $33+345+689+7+275=1349$ more results for smart text search and 15 (b) of them taken into consideration for being relevant. Consequently, $37(a+b)$ hits were attained as the final pool.

\subsection{Preparation of the Survey}

Among the 37 articles, a set of indicators were chosen to be included in the draft survey. This draft survey was verified with three finance industry experts, who work in credit allocation, project finance and credit scoring areas, by face-to-face interviews. The selected indicators and their sources can be found in appendix 1.

The selected indicators were classified into the groups. There were also open-ended questions under each group. As a result, the survey has four main groups (number of indicators in parenthesis, 43 indicators total except open-ended questions):

Firm Characteristics (7)

Owner / Founder Characteristics (6)

Financial Characteristics (18)

Marketing / Procurement Characteristics (12)

In each group, the following open-ended questions were included to let the respondents in adding extra indicators or comment on existing indicators:

- Do your answers for the criteria above change according to the stage of start-up? If yes, which of them?

- Do you have other indicators considered when evaluating FinTechs?

The summary of the answers are presented and discussed in Findings and Discussions sections.

\subsection{Execution of the Survey}

To select the investors who would participate in the survey, data from startups.watch platform and FinTech meetups in Turkey were used as the main sources:

Startups.watch is an online platform, which you can obtain 'data, insights and reports about Turkish Startup Ecosystem'. In October 2016, 12 venture capitalists, 2 private equities, 1 financial institution and 13 personal investors were registered in startups.watch platform (http://Startups.watch) as 'invested' or 'planning to invest' in FinTech startups in Turkey. Angel investors weren't identified in this list and they were remarked as 'undisclosed angel investor'.

FinTech meetups (namely FinTech Angels Meetup and FinTech Forum 2016 in Istanbul) were also used to reach FinTech investors. New connections were obtained in these meetings by snowball sampling, which is widely used in 'difficult to access populations' like angel investors.

Appointments for interviews have been requested from authorities in VCs, Private Equities and angel investors by using convenience sampling. Four angels and four VCs responded to our request. The questions were covered in face-to-face interviews with the decision-maker level people from responding four angels (one of them being a corporate funding officer at the same time) and four VCs.

\section{FINDINGS AND DISCUSSIONS}

Frequency analysis results for each criteria group can be found in the tables below. According to frequency analyses, it is observed that, some indicators were preferred more by the respondents (The number of respondents, who indicated the criterion as important, is given in "frequency" columns in the following tables).

\subsection{Firm Characteristics}

For the firm characteristics group, ownership issues like the number of shareholders, the distributions of shares among shareholders and shareholder structure have been identified as important factors for their investment decisions by all interviewees. The sector the company operates in and the rise in the employee expenditures are indicated by six and five out of eight, respectively. 
Table 1: Firm Characteristics Indicators

\begin{tabular}{|l|l|c|c|}
\hline No & Criteria & Frequency & $\%$ \\
\hline 1 & $\begin{array}{l}\text { Shareholder structure, the distribution of shares among shareholders, number of } \\
\text { shareholders }\end{array}$ & 8 & $100 \%$ \\
\hline 2 & $\begin{array}{l}\text { The sector the company operates in (Payment systems? Prepaid card? E-Gov? } \\
\text { Wallet? etc.) }\end{array}$ & 6 & $75 \%$ \\
\hline 3 & Rise in employee expenditure & 5 & $63 \%$ \\
\hline 4 & Number of Board or Advisors & 4 & $50 \%$ \\
\hline 5 & Number of employees & 3 & $38 \%$ \\
\hline 6 & Rise in the number of employees & 2 & $25 \%$ \\
\hline 7 & Foundation year & $38 \%$ \\
\hline
\end{tabular}

These results in Table 1 are in accordance with Miloud et al. (2012) and indirectly with Eckhardt et al. (2006), Groenewegen and Langen (2012). Number of board or advisors has been identified by half of the investors. The number of employees and their rise in numbers have chosen by three out of eight. The least preferred factor was the foundation year by being indicated only twice.

\subsection{Owner / Founder Characteristics}

For the owner / founder characteristics group, all of the respondents identified the experience of major decision makers as a base for their decisions. Major decision maker's education and number of major decision maker are also widely accepted (Table 2). Supporting these results, MacMillan et al. (1986) found the quality of entrepreneur as the ultimate decision determinant for venture capital community. Chang (2013) indicated that VCs and accelerators stress entrepreneur characteristics in their selection. Miloud et al. (2004) found a positive effect of the founder quality, on funding decisions. Nofsinger and Wang (2011), An, Jung and Hee-Woong (2015), Nuscheler (2016) also mentioned the importance of human capital and experience. Cassar (2014) indicated the benefits of experience on forecast performance. Marion (2016) and Staniewski (2016) claimed experience and graduation from top schools predicted founder success. Major decision maker's age has been indicated as important by half of the interviewees, but they didn't mention whether it is preferable being young or old. So it is hard to claim that this is in accordance with Marion (2016)'s findings of younger entrepreneurs' tendency to be more successful.

\section{Table 2: Owner / Founder Characteristics Indicators}

\begin{tabular}{|l|l|c|c|}
\hline No & Criteria & Frequency & $\%$ \\
\hline 1 & $\begin{array}{l}\text { Experience of major decision maker(s) (Start-up experience (sector), start-up } \\
\text { experience (non-sector), salaried experience (sector), salaried experience (non- } \\
\text { sector), other) }\end{array}$ & 8 & $100 \%$ \\
\hline 2 & Number of major decision maker(s) & 7 & $88 \%$ \\
\hline 3 & Major decision maker(s)' education, the school they graduated, etc. & 7 & $88 \%$ \\
\hline 4 & Age of major decision maker(s) & 4 & $50 \%$ \\
\hline 5 & Marital status of major decision maker(s) & 2 & $25 \%$ \\
\hline 6 & Gender of major decision maker(s) & 0 & $0 \%$ \\
\hline
\end{tabular}

Major decision maker's marital status have been counted as important only twice, and gender has been indicated by none of the investors in contrary to the claim of Marion (2016), which addresses the existence of at least one female founder in highperforming investments. We can say these findings give rise to a thought for some kind of equal opportunity in investment decision phase. Business network has emerged as an important issue in open-ended questions, in accordance with Miloud et al. (2012) and Falik et al. (2016). The relationship between the founders, their dedication and vision, founder's capability on marketing and sales, and regulations were also emphasized.

\subsection{Financial Characteristics}

For the financial characteristics group, all respondents indicated increase in net sales, whether it held VC funding and its amount, whether it had other funding sources and their amounts as important factors for their decisions in accordance with Eckhardt et al. (2006) (Table 3). 
Table 3: Financial Characteristics Indicators

\begin{tabular}{|l|l|c|c|}
\hline No & Criteria & Frequency & $\%$ \\
\hline 1 & Increase in net sales & 8 & $100 \%$ \\
\hline 2 & VC funding? If yes, the stage it has been taken and the funding amount (TL or FX) & 8 & $100 \%$ \\
\hline 3 & $\begin{array}{l}\text { Other funding sources used? (Family, friends, etc.) If yes, what is the source and the } \\
\text { amount? (TL or FX) }\end{array}$ & 8 & $100 \%$ \\
\hline 4 & Gross sales & 7 & $88 \%$ \\
\hline 5 & Net sales & 7 & $88 \%$ \\
\hline 6 & Operating Margin (Operating Profit / Net Sales) & 7 & $88 \%$ \\
\hline 7 & Any bank loan? If yes, amount (TL or FX)? & 7 & $88 \%$ \\
\hline 8 & Earnings Before Interest, Taxes, Depreciation, And Amortization (EBITDA) & 6 & $75 \%$ \\
\hline 9 & Increase in net income & 6 & $75 \%$ \\
\hline 10 & Net Income Margin (Net Income / Net Sales) & 6 & $75 \%$ \\
\hline 11 & Net Cash Flow (Operating Profit + All Non-cash Expense (i.e. Amortisation)) & 6 & $75 \%$ \\
\hline 12 & Net income & 5 & $63 \%$ \\
\hline 13 & Balance Sheet Asset Size & 3 & $38 \%$ \\
\hline 14 & Current Ratio (Current Assets / Current Liabilities) & 3 & $38 \%$ \\
\hline 15 & Leverage Ratio (Total Liabilities / Total Shareholders' Equity) & 3 & $38 \%$ \\
\hline 16 & Liquidity (Acid Test) Ratio (Current Assets - Inventory) / Current Liabilities) & 3 & $38 \%$ \\
\hline 17 & EBITDA / Short Term Debts & 3 & $38 \%$ \\
\hline 18 & Dividend & 2 & $25 \%$ \\
\hline
\end{tabular}

Åstebro and Bernhardt (2003) found bank loan's negative effects on business survival when compared to other sources. Also, one of our angels remarked he doesn't find logical to invest in a FinTech, which used a bank loan. All but one claimed Gross Sales, Net Sales, Operating Margin (Operating Profit / Net Sales), whether it held bank loans and its amount as determinants for funding. An, Jung and Hee-Woong (2015) also underlined the importance of past investors in the startup. Six of the interviewees counted in Earnings Before Interest, Taxes, Depreciation, and Amortization (EBITDA), Increase in net income, Net Income Margin and Net Cash Flow. Only five expressed Net Income as important. Chang (2013) found that VCs put more weight on 5 to 10 years' financial return, than accelerators did, but such difference weren't observed in this sample.

Balance Sheet Asset Size, Current Ratio, Leverage Ratio, Liquidity (Acid Test) Ratio, EBITDA / Short Term Debts and Dividend are the least favored indicators among our respondents. Cassar (2004) found size and noncurrent assets weigh more than major decision maker's characteristics, but it can't be counted as valid for the sample in this study.

\subsection{Marketing / Procurement Characteristics}

When it comes to the marketing / procurement characteristics group, all of the respondents counted the number of clients, expected developments in the industry, serving to consumers or businesses (Being B2B or B2C) in as important indicators in their decision-making processes. Our respondents also remarked the differentiation in the importance of the number of clients and other competition issues according to the stage the company belongs (Table 4).

Table 4: Marketing / Procurement Indicators

\begin{tabular}{|l|l|c|c|}
\hline No & Criteria & Frequency & $\%$ \\
\hline 1 & Number of clients & 8 & $100 \%$ \\
\hline 2 & Expected developments in the industry & 8 & $100 \%$ \\
\hline 3 & Serving to consumers or businesses (Being B2B or B2C) & 8 & $100 \%$ \\
\hline 4 & Number of competitor firms in the sector the startup is operating in & 7 & $88 \%$ \\
\hline 5 & Annual growth rate of the competitors (considering sales and income) & 7 & $88 \%$ \\
\hline 6 & Does the firm present a brand-new product or improve an existing product? & 6 & $75 \%$ \\
\hline 7 & The distribution of sales among clients (\%) & 6 & $75 \%$ \\
\hline 8 & $80 \%$ of the sales come from what percentage of the customers? & 6 & $75 \%$ \\
\hline 9 & The share of the startup in the industry (considering sales) & 6 & $75 \%$ \\
\hline 10 & $\begin{array}{l}\text { The distribution of goods \& services obtained from suppliers among total goods \& } \\
\text { services }\end{array}$ & 5 & $63 \%$ \\
\hline
\end{tabular}




\begin{tabular}{|l|l|c|c|}
\hline 11 & $\begin{array}{l}80 \% \text { of the goods \& services obtained from suppliers come from what percentage of } \\
\text { the suppliers? }\end{array}$ & 5 & $63 \%$ \\
\hline 12 & Does the firm take actions in social responsibility issues? & 3 & $38 \%$ \\
\hline
\end{tabular}

This is in accordance with the findings of Nuscheler (2016). Seven out of eight claimed they mind the number of competitor firms in the sector the startup is operating in and annual growth rate of the competitors (considering sales and income). A significant difference between angels and VCs emphasizing on entering high-growth market with little competition, weren't observed in this study, unlike Chang (2013). Indicators about whether the firm presented a brand-new product or improved an existing product, customer percentage for $80 \%$ of the sales, the sales share of the startup in the industry were chosen by six, the distribution of goods \& services obtained from suppliers among total goods \& services, supplier percentage for $80 \%$ of the goods \& services were chosen by five, more than half. Only three respondents accepted whether the firm took actions in social responsibility issues as a criterion, whereas one of them implying this as a negative point, which meant spending the money they give for scaling, on another issue; and one of them as the opposite, positive, whether it did any impact on social or environmental issues.

\section{CONCLUSION}

This research, which might give useful insights to the investors for the indicators to use in FinTech investment decision-making processes in Turkey. FinTech startups may also benefit from the findings to understand the investors' motivation in their search for funding. The major findings of this study can be summarized as follows:

\subsection{Firm Characteristics}

Shareholder structure and entrepreneur's share in the company are important factors. Low share of an entrepreneur is expected to decrease the motivation of the entrepreneurs. It isn't necessary for Founder to have the major share. The crucial thing is having a solid share amount.

If the company is far from any achievements for a very long time, then it is not suitable for an Angel Investor. As this fact supports, FinTech's up-to-date sales size, API connections, partners, number of employees depending on sector (i.e. for payment systems five people is not enough whereas for budget two is more than enough because there are regulations for the number of employees) were in account besides shareholder structure and distribution of shares.

Regulations play a major role in the FinTech investment. For instance, IT infrastructure's location is considered important according to BRSA regulations. BRSA requires main servers to reside in Turkey.

\subsection{Owner / Founder Characteristics}

Investors invest in founders' personality, skill, knowledge and business network power. Founders' capability in marketing and sales are quoted as crucial, but comes with a difficulty in measurement. They usually compare entrepreneurs' capabilities with that of his / her competitors when deciding to invest.

Age is not identified as vital, because the key issues, which are responsibility or dedication, have nothing to do with age. However, every age group has its own dilemmas: Some young people may not take things seriously and some old people may turn into a deaf ear on investor's advices. It is implied that the best ages for an entrepreneur is between 27 and 40.

Education loses its importance when the entrepreneur holds the business logic. In addition, homogeneous team composition (i.e. only coders or only bankers) appears as a negative point for FinTechs. Investors add the importance of the balance and sharing of the workload between founders. The relationship is expected to be on mutual trust and understanding.

In a FinTech startup, one of the entrepreneurs' being a software developer and the other's being a financial specialist is highly preferred.

\subsection{Financial Characteristics}

Investing in a FinTech which used a bank loan is not found as logical. Current EBITDA and Cash Flow are not considered as important, but projections on EBITDA and cash flow are dominating their current values in the minds of investors.

Billing amount per deal is also an indicator. 'How many customers are lost when gaining new customers?' and 'Does sales increase come from promotions or on its own?' are expressed as helpful questions in shaping the investment decision.

\subsection{Marketing / Procurement Characteristics}

Quality or the characteristic of the product is the key issue, not the firm. The focus is the product that meets the market first. Therefore, product characteristics appear as the critical attribute. What is critical for a product is its fit to the market. Product- 
market fit is signified with a drawback for brand new products in creating its own market. Sometimes a brand-new product can be risky because of its obligation and hardness to generate its own market. The readiness of the market may determine the survival of the product and the company.

Serving $B 2 B$ or $B 2 C$ are outstanding important for different scenarios. The number of the clients and their balanced distribution are crucial factors if the FinTech serves as B2B, because shifting companies from one product to another requires hard work while shifting consumers is far easier. Customer acquisition costs become the most important factor if FinTech serves as B2C. B2B's having lower expenses can be advantageous, but B2B market penetration's being harder can be disadvantageous on the other side.

The number of competitors is important, but the market size may overwhelm the number of competitors if the market is big enough to offer opportunities for more players.

Interviewees were aware of the oddness in $80 \%$ of income coming from $20 \%$ of the customers, but they consider this as a risk only if those $20 \%$ customers were one or two companies. This holds for the suppliers' part. However, this fact does not avoid investors from investing; it leads to taking extra measures.

Involvement in social responsibility projects are not preferred by investors, because it is considered as a concentration disturbing fact for FinTechs due to their being profit driven organizations. The return on investment is measured by the profit gained, not by the allocation to social responsibility issues. Dedication to social responsibility is considered as latter a stage activity.

Outsourcing proportion is crucial for a FinTech company. Investors do have a bad opinion about too much outsourcing. Being dependent to a foreign company or founder is a negative mark for a FinTech startup.

Billing amount per deal, customers' acquisition-retention rates and origin of the sales increase are also important in investment decisions.

The result of this research shows that it is possible to group the decision-making criteria of investors into four categories and some indicators within each category are underlined. The outstanding criteria in the research are also counted as important measures in the literature. Therefore, investors and FinTech entrepreneurs can use this research as a quick list during investment decision process or business modelling activities.

Although this research has a valuable contribution to the Turkish FinTech ecosystem, there exist some limitations in this study as well. First of all, our sample size is limited to a number of eight investors operating in Istanbul. Findings of this study do not represent the whole FinTech Ecosystem in Turkey. It would be enlightening to expand the size and location in sampling for further studies on FinTech investments. Future research may include investigations on FinTech investments by segmenting the clients, service types, startup stages and investor types.

\section{REFERENCES}

360Leaders (2016). FinTech Map 2016. Retrieved from http://360leaders.net/wp-content/uploads/2016/09/FinTech-CaseStudy Web Final.pdf

Accenture (2015, December 5). The Future of FinTech and Banking: Digitally disrupted or reimagined? London: Accenture. Retrieved from http://www.FinTechinnovationlablondon.co.uk/media/730274/Accenture-The-Future-of-FinTech-and-Banking-digitallydisrupted-or-reimapdf

Accenture Report (2016, December 3). FinTech and the evolving landscape: landing points for the industry. Retrieved from http://www.FinTechinnovationlabapac.com/media/1157/FinTech Evolving Landscape 2016.pdf

An J., Jung W., Hee-Woong K. (2015, December 4). A Green Flag over Mobile Industry Start-Ups: Human Capital and Past Investors as Investment Signals. PACIS 2015 Proceedings, Paper 67. Retrieved from http://aisel.aisnet.org/pacis2015/67

Anon (2013, December 23). Facebook Banking Takes Off In Turkey. Retrieved from www.pymnts.com/uncategorized/2013/facebookbanking-takes-off-in-turkey

Arner, D.W., Barberis, J., Buckley, R.P. (2015). The Evolution of FinTech: A New Post-Crisis Paradigm?. University of Hong Kong Faculty of Law Research Paper No: 2015/047.

Åstebro, T., Bernhardt, I. (2003). Start-up financing, owner characteristics, and survival. Journal of Economics and Business. Volume 55, Issue 4, pp. 303-319. 
Baum, J.A.C., Silverman, B.S. (2004). Picking winners or building them? Alliance, intellectual, and human capital as selection criteria in venture financing and performance of biotechnology startups. Journal of Business Venturing. 19, pp. 411-436.

Belli, M. (2016). Banking and FinTech: Developing a FinTech Ecosystem in Istanbul Learning Lessons From London. e-book, retrieved from http://bkm.com.tr/wp-content/uploads/2016/02/Banking-and-FinTech.pdf

Boteler, D. (2014, December 4). FinTech: a new definition, What is FinTech?. Grovelands Recruitment. Retrieved from

www.grovelands.co.uk/FinTech/\#sthash.J9WKQ6Ft.dpuf

Canko, S. (2017). FinTech Finans Dünyasını Yeniden Şekillendiriyor. FinTech Istanbul Booklet from Capital Monthly Business and Economics Magazine. January 2017.

Capital (2017-1). Türkiye FinTech'te Önemli Bir Yer Edinecek, Interview with İhsan Elgin. FinTech İstanbul Booklet from Monthly Business and Economics Magazine. January 2017.

Capital (2017-2), Infographic and Research Tables. FinTech Istanbul Booklet from Monthly Business and Economics Magazine. January 2017. Cassar, G. (2004). The financing of business start-ups. Journal of Business Venturing. 19. pp. 261-283.

Cassar, G. (2014. Industry and startup experience on entrepreneur forecast performance in new firms. Journal of Business Venturing. 29. pp.137-151.

Cengiz, D.D. (2017). Fintek Hareketi Bir Devrim Mi?. Fintechtime Finance and Technology Magazine. N.4. Winter 2016/17. pp. 120-121.

Chang, C. (2013, December 4). Portfolio Company Selection Criteria: Accelerators vs Venture Capitalists. CMC Senior Theses. Paper 566. Retrieved from http://scholarship.claremont.edu/cmc theses/566

Cornish, D. (2013, December 4). Europe's hottest startup capitals: Istanbul. Retrieved from www.wired.co.uk/magazine/archive/2013/11/european-startups/istanbul

Csaszar, F., Nussbaum M., Sepulveda M. (2006). Strategic and cognitive criteria for the selection of startups. Technovation. 26,.pp.151-161.

Cusumano, M.A. (2013). Technology Strategy and management Evaluating a Startup venture. Communications of the ACM. Vol. 56. No. 10, pp. 26-29.

Davila, A., Foster G. (2005). Management Accounting Systems Adoption Decisions: Evidence and Performance Implications from EarlyStage/Startup Companies. The Accounting Review. Vol. 80. No. 4. pp. 1039-1068.

Drucker, V. (2013, December 4). Global Finance (2013) Special Report: Turkish Banking. December 2013, London: Global Finance. Retrieved from www.gfmag.com/magazine/december-2013/special-report-turkish-banking

Eckhardt, J.T., Shane, S., Delmar, F. (2006). Multistage Selection and the Financing of New Ventures. Management Science. Vol. 52, No. 2, pp, $220-232$

Ensley, M.D., Hmieleski, K.M., Pearce, C.L. (2006). The importance of vertical and shared leadership within new venture top management teams: Implications for the performance of startups. The Leadership Quarterly. 17. pp. 217-231.

Ensor, B. (2012, December 4). Digital Banking Innovation In Turkey. Retrieved from http://blogs.forrester.com/benjamin ensor/12-09-18digital_banking innovation in turkey

Ernst \& Young (2013). Ernst \& Young's attractiveness survey, Turkey 2013: The shift, the growth and the promise. Istanbul: EYGM Limited, EYG no. AU1579.

Falik, Y., Lahti T., Keinonen, H. (2016). Does startup experience matter? Venture capital selection criteria among Israeli entrepreneurs. Venture Capital. 18:2, pp. 149-174.

Groenewegen, G., Langen, F. (2012),. Critical Success Factors of the Survival of Start-Ups with a Radical Innovation. Journal of Applied Economics and Business Research JAEBR. 2(3). pp. 155-171.

Haddad, C., Hornuf, L. (2016, December 4). The Emergence of the Global FinTech Market: Economic and Technological Determinants. CESifo Working Paper Series No. 6131. Retrieved from http://ssrn.com/abstract=2830124

Independent Report by EY for HM Treasury (2016, December 4). UK FinTech On the cutting edge: An evaluation of the international FinTech $\begin{array}{lllll}\text { sector } & 24 & \text { Feb } & 2016 . & \text { Retrieved }\end{array}$ https://www.gov.uk/government/uploads/system/uploads/attachment data/file/502995/UK FinTech - On the cutting edge Full Report.pdf

ING International (2015). The rise of mobile banking and the changing face of payments in the digital age, Mobile Banking, Social Media and Financial Behaviour. ING International Survey, April 2015, Amsterdam.

Karabayır, M.E., Gülşen, A.Z., Çifci, S., Muzaffar, H. (2012). Melek Yatırımcıların Kararlarında Girişimci Odaklılığın Rolü: Türkiye'deki Melek Yatırımcılar Üzerine Bir Çalışma. Ankara Üniversitesi Siyasal Bilgiler Fakültesi Dergisi. Cilt 67. No. 2. s.69-93. 
Kłobukowski P., Pasieczny J. (2016, December 4). Business Models Of Startups In Cooperation With Mature Companies - Obtaining Orders And Building A Leading Position On The Market. Zeszyty Naukowe Politechniki PoznańSkiej Nr 68 Organizacja i Zarządzanie. Retrieved from http://zeszyty.fem.put.poznan.pl/

KPMG and H2 Ventures, (2016, December 4). 2016 FiNTECH100 Leading Global FinTech Innovators Report. Retrieved from https://home.kpmg.com/au/en/home/insights/2016/10/FinTech-100-leading-global-innovators.html

Letstalkpayments, (2016, December 4). 22 FinTech Accelerators Fostering Innovation in the Financial Services Industry. Retrieved from https://letstalkpayments.com/22-FinTech-accelerators-fostering-innovation-in-the-financial-services-industry/

MacMillan, I. C., Siegel, R., Narasimha, P. S. (1986). Criteria used by venture capitalists to evaluate new venture proposals. Journal of Business venturing, 1(1). pp. 119-128.

Marion, T. (2016). 4 Factors That Predict Startup Success, and One That Doesn't. J. Harvard Business Review Digital Articles. 5/3/2016. pp. 2-

MasterCard (2016, December 22). MasterCard Mobile Readiness Country Comparisons. Retrieved from http://mobilereadiness.mastercard.com/country-comparisons

McKinsey \& Company (2016, December 4). Cutting Through the FinTech Noise: Markers of Success, Imperatives For Banks, Feb 2016. Retrieved from http://www.mckinsey.com/industries/financial-services/our-insights/cutting-through-the-noise-around-financialtechnology

Miloud, T., Aspelund, A., Cabrol, M. (2012). Startup valuation by venture capitalists: an empirical study. Venture Capital Vol. 14. Nos. 2-3, pp. 151-174.

Munch, J. (2014, December 4). What is FinTech and why does it matter to all entrepreneurs? July 2014. Retrieved from https://www.hottopics.ht/stories/finance/what-is-FinTech-and-why-it-matters/

Nanda, R., Rhodes-Kropf M. (2013). Investment cycles and startup innovation. Journal of Financial Economics 110,.pp. 403-418.

National Digital Research Centre (NDRC) (2014, December 4). So what is FinTech? March 2014. Retrieved from www.ndrc.ie/2014/03/FinTech

Nofsinger, J.R., Wang W. (2011). Determinants of start-up firm external financing worldwide. Journal of Banking \& Finance 35. pp. 22822294.

Nuscheler D. (2016, December 4). Regularly change a running system! An analysis of stage-specific criteria for attracting venture capital and changing the likelihood for getting funded. 3IFABS best poster award. Retrieved from http://ifabs.org/assets/stores/1206/userfiles/3IFABS\%20Best\%20Poster\%20Award\%20-

\%20Daniela\%20Nuscheler\%2C\%20TU\%20Dortmund\%20University\%2C\%20DE.pdf

Parker, S.C. (2009). The Economics of Entrepreneurship. Cambridge University Press. NY USA.

Price Waterhouse Coopers (2016, December 4). Blurred lines: How FinTech is shaping Financial Services. Global FinTech Report, March 2016. Retrieved from http://www.pwc.com/gx/en/advisory-services/FinTech/PwC\%20FinTech\%20Global\%20Report.pdf

Rozen, H. (2015). The Relationship Between Firm Performance and the Market's Trust in Security Estimates: Evidence from the Public Venture Capital Industry. Journal of Accounting and Finance. Vol. 15(4). pp.183-195.

Sironi, P. (2016), FinTech Innovation: From Robo-Advisors to Goal Based Investing and Gamification, UK: Wiley.

Staniewski, M. W. (2016). The contribution of business experience and knowledge to successful entrepreneurship . Journal of Business Research. 69. pp. 5147-5152.

The Banks Association of Turkey (BAT) (2016, December 4), Internet and Mobile Banking Statistics. Istanbul: BAT September 2016. Retrieved from https://www.tbb.org.tr/tr/bankacilik/banka-ve-sektor-bilgileri/istatistiki-raporlar/59

Wimmer, J.P.J. (2016). Unraveling the entrepreneurial process: Exploring the role of business models in opportunity-creation. Unpublished Masters thesis. Retrieved from http://purl.utwente.nl/essays/69422, March 2016, Uni of Twente, Berlin.

Yazici, S, (2017). Yatırımcıların İlgisi Artıyor, Interview with Selim Yazıcı. FinTech istanbul Booklet from Capital Monthly Business and Economics Magazine. January 2017. 
Appendix 1: Investment Criteria and References

\begin{tabular}{|l|l|}
\hline Firm Characteristics & References \\
\hline $\begin{array}{l}\text { Shareholder structure, the distribution of shares } \\
\text { among shareholders, number of shareholders }\end{array}$ & $\begin{array}{l}\text { Groenewegen and Langen (2012) Åstebro and Bernhardt (2003) } \\
\text { Nofsinger and Wang (2011) Ensley et al. (2006) Miloud et al.(2012) } \\
\text { MacMillan, Siegel and Narasimha (1986) Chang (2013) }\end{array}$ \\
\hline $\begin{array}{l}\text { The sector the company operates in (Payment } \\
\text { systems? Prepaid card? E-Gov? Wallet? etc.) }\end{array}$ & Davila and Foster (2005) Falik et al. (2016) Parker (2009) \\
\hline Rise in employee expenditure & Financial Expert Opinion \\
\hline Number of Board or Advisors & $\begin{array}{l}\text { Groenewegen and Langen (2012) Nuscheler (2016) An et al. (2015) } \\
\text { Ensley et al. (2006) Cusumano (2013) Miloud et al. (2012) }\end{array}$ \\
\hline Number of employees & An et al. (2015) Wimmer (2016) Davila and Foster (2005) \\
\hline Foundation year & $\begin{array}{l}\text { Wimmer (2016) Baum and Silverman (2004) Ensley et al. (2006) } \\
\text { Eckhardt et al.(2006) Davila and Foster (2005) Miloud et al. (2012) } \\
\text { Nuscheler (2016) }\end{array}$ \\
\hline Rise in the number of employees & $\begin{array}{l}\text { Davila and Foster (2005) Ensley et al. (2006) Groenewegen and Langen } \\
\text { (2012) }\end{array}$ \\
\hline
\end{tabular}

\begin{tabular}{|l|}
\hline Owner / Founder Characteristics \\
\hline Number of major decision maker(s) \\
\hline $\begin{array}{l}\text { Experience of major decision maker(s) (Start-up } \\
\text { experience (sector), start-up experience (non-sector), } \\
\text { salaried experience (sector), salaried experience (non- } \\
\text { sector), other) }\end{array}$ \\
\hline $\begin{array}{l}\text { Major decision maker(s)' education, the school they } \\
\text { graduated, etc. }\end{array}$
\end{tabular}

Marital status of major decision maker(s)

Age of major decision maker(s)

Gender of major decision maker(s)

\section{References}

Davila and Foster (2005)

Csaszar et al. (2006) Groenewegen and Langen (2012) Cassar (2004) Åstebro and Bernhardt (2003) Nuscheler (2016) Nofsinger and Wang (2011) Baum and Silverman (2004) Chang (2013) Staniewski (2016) Cassar (2014) Eckhardt et al. (2006) Davila and Foster (2005) Marion (2016) Cusumano (2013) Miloud et al. (2012) Falik et al. (2016) Parker (2009) MacMillan et al. (1986)

Groenewegen and Langen (2012) Cassar (2004) Nuscheler (2016) Nofsinger and Wang (2011) Cassar (2014) Davila and Foster (2005) Marion (2016) Parker (2009) Åstebro and Bernhardt (2003) Parker (2009)

Nofsinger and Wang (2011) Cassar (2004) Cassar (2014) Marion (2016) Falik et al. (2016) Parker (2009)

Nofsinger and Wang (2011) Cassar (2004) Cassar (2014) Marion (2016)

Falik et al. (2016) Parker (2009)

\begin{tabular}{|l|l|}
\hline Financial Characteristics & References \\
\hline Increase in net sales & $\begin{array}{l}\text { Nuscheler (2016) Cassar (2004) Nofsinger and Wang (2011) Eckhardt et } \\
\text { al. (2006) Cusumano (2013) }\end{array}$ \\
\hline $\begin{array}{l}\text { VC funding? If yes, the stage it has been taken and the } \\
\text { funding amount (TL or FX) }\end{array}$ & $\begin{array}{l}\text { Groenewegen and Langen (2012) Nuscheler (2016) An et al. (2015) } \\
\text { Davila and Foster (2005) Cusumano (2013) Falik et al. (2016) }\end{array}$ \\
\hline $\begin{array}{l}\text { Other funding sources used? (Family, friends, etc.) If } \\
\text { yes, what is the source and the amount? (TL or FX) }\end{array}$ & Nofsinger and Wang (2011) Davila and Foster (2005) \\
\hline Gross sales & Nuscheler (2016) \\
\hline Net sales & Staniewski (2016) Eckhardt et al. (2006) Davila and Foster (2005) \\
\hline Operating Margin (Operating Profit / Net Sales) & Financial Expert Opinion \\
\hline Any bank loan? If yes, amount (TL or FX)? & Nanda and Rhodes-Kropf (2013) \\
\hline $\begin{array}{l}\text { Earnings Before Interest, Taxes, Depreciation, And } \\
\text { Amortization (EBITDA) }\end{array}$ & Financial Expert Opinion \\
\hline Increase in net income & Ensley et al. (2006) Davila and Foster (2005) Cusumano (2013) \\
\hline Net Income Margin (Net Income / Net Sales) & Financial Expert Opinion \\
\hline $\begin{array}{l}\text { Net Cash Flow (Operating Profit + All Non-cash Expense } \\
\text { (i.e. Amortization)) }\end{array}$ & Baum and Silverman (2004) Csaszar et al. (2006) \\
\hline Net income & $\begin{array}{l}\text { Baum and Silverman (2004) Staniewski (2016) Davila and Foster (2005) } \\
\text { Miloud et al. (2012) }\end{array}$ \\
\hline Balance Sheet Asset Size & $\begin{array}{l}\text { Nofsinger and Wang (2011) Cassar (2004) Baum and Silverman (2004) } \\
\text { Chang (2013) Falik et al. (2016 }\end{array}$ \\
\hline
\end{tabular}




\begin{tabular}{|l|l|}
\hline EBITDA / Short Term Debts & Financial Expert Opinion \\
\hline Dividend & Financial Expert Opinion \\
\hline Current Ratio (Current Assets / Current Liabilities) & Financial Expert Opinion \\
\hline $\begin{array}{l}\text { Leverage Ratio (Total Liabilities / Total Shareholders' } \\
\text { Equity) }\end{array}$ & Nofsinger and Wang (2011) Cassar (2004) \\
\hline $\begin{array}{l}\text { Liquidity (Acid Test) Ratio ((Current Assets - Inventory) } \\
\text { / Current Liabilities) }\end{array}$ & Staniewski (2016) Cassar (2004) \\
\hline
\end{tabular}

\begin{tabular}{|l|l|}
\hline Marketing / Procurement Characteristics & References \\
\hline Number of clients & $\begin{array}{l}\text { Chang (2013) Cusumano (2013) Parker (2009) MacMillan et al. (1986) } \\
\text { Csaszar et al. (2006) }\end{array}$ \\
\hline $\begin{array}{l}\text { Number of competitor firms in the sector the startup is } \\
\text { operating in }\end{array}$ & $\begin{array}{l}\text { Astebro and Bernhardt (2003) Nanda and Rhodes-Kropf (2013) Baum } \\
\text { and Silverman (2004) Eckhardt et al.(2006) Cusumano (2013) Parker } \\
\text { (2009) }\end{array}$ \\
\hline $\begin{array}{l}\text { Does the firm present a brand-new product or improve } \\
\text { an existing product? }\end{array}$ & $\begin{array}{l}\text { Groenewegen and Langen (2012) Nofsinger and Wang (2011) Chang } \\
\text { (2013) Staniewski (2016) Cusumano (2013) MacMillan et al. (1986) }\end{array}$ \\
\hline Expected developments in the industry & Cusumano (2013) Parker (2009) \\
\hline Serving to consumers or businesses (Being B2B or B2C) & Wimmer (2016) \\
\hline $\begin{array}{l}\text { Annual growth rate of the competitors (considering } \\
\text { sales and income) }\end{array}$ & Nuscheler (2016) Miloud et al. (2012) MacMillan et al. (1986) \\
\hline The distribution of sales among clients (\%) & Financial Expert Opinion \\
\hline $\begin{array}{l}\text { 80\% of the sales come from what percentage of the } \\
\text { customers? }\end{array}$ & Financial Expert Opinion \\
\hline $\begin{array}{l}\text { The share of the startup in the industry (considering } \\
\text { sales) }\end{array}$ & $\begin{array}{l}\text { Nuscheler (2016) Chang (2013) Staniewski (2016) Eckhardt et al.(2006) } \\
\text { Cusumano (2013) Miloud et al. (2012) }\end{array}$ \\
\hline $\begin{array}{l}\text { The distribution of goods \& services obtained from } \\
\text { suppliers among total goods \& services }\end{array}$ & Financial Expert Opinion \\
\hline $\begin{array}{l}\text { 80\% of the goods \& services obtained from suppliers } \\
\text { come from what percentage of the suppliers? }\end{array}$ & Financial Expert Opinion \\
\hline $\begin{array}{l}\text { Does the firm take actions in social responsibility } \\
\text { issues? }\end{array}$ & Financial Expert Opinion \\
\hline
\end{tabular}

